\title{
Hypoxia regulates the expression and localization of CCAAT/enhancer binding protein $\alpha$ by hypoxia inducible factor-1 $\alpha$ in bladder transitional carcinoma cells
}

\author{
MEI XUE ${ }^{1}, \mathrm{XU} \mathrm{LI}^{1}$ and WEI CHEN ${ }^{2}$ \\ ${ }^{1}$ Center for Translational Medicine, ${ }^{2}$ Department of Laboratory Medicine, The First Affiliated Hospital, \\ School of Medicine, Xi'an Jiaotong University, Xi'an, Shaanxi 710061, P.R. China
}

Received December 26, 2013; Accepted March 16, 2015

DOI: $10.3892 / \mathrm{mmr} .2015 .3563$

\begin{abstract}
Hypoxia inducible factor- $1 \alpha(\mathrm{HIF}-1 \alpha)$ is overexpressed in various types of solid tumor in humans, including bladder cancer. HIF-1 $\alpha$ regulates the expression of a series of genes, which are involved in cell proliferation, differentiation, apoptosis, angiogenesis, migration and invasion and represents a potential therapeutic target for the treatment of human cancer. Despite extensive investigation of the effects of HIF-1 $\alpha$ in the progression and metastasis of bladder cancer, the possible regulatory mechanisms underlying the effects of HIF-1 $\alpha$ on bladder cancer cell proliferation and differentiation remain to be elucidated. It has been suggested that the transcription factor CCAAT/enhancer binding protein $\alpha(\mathrm{C} / \mathrm{EBP} \alpha)$ acts as a tumor suppressor in several types of cancer cell, which are involved in regulating cell differentiation, proliferation and apoptosis. The present study confirmed that, in bladder cancer cells, the expression and localization of $\mathrm{C} / \mathrm{EBP} \alpha$ was regulated by hypoxia through an HIF-1 $\alpha$-dependent mechanism, which may be significant in bladder cancer cell proliferation and differentiation. The 5637 and T24 bladder cancer cell lines were incubated under normoxic and hypoxic conditions. The expression levels of HIF-1 $\alpha$ and $\mathrm{C} / \mathrm{EBP} \alpha$ were detected by reverse transcription-quantitative polymerase chain reaction, western blotting and immunofluorescence analysis. The results revealed that, under hypoxic conditions, the protein expression levels of HIF-1 $\alpha$ were markedly upregulated, but the mRNA levels were not altered. However, the mRNA and protein levels of $\mathrm{C} / \mathrm{EBP} \alpha$ were significantly reduced. The present study further analyzed the subcellular
\end{abstract}

Correspondence to: Dr Wei Chen, Department of Laboratory Medicine, The First Affiliated Hospital, School of Medicine, Xi'an Jiaotong University, 277 West Yanta Road, Xi'an, Shaanxi 710061, P.R. China

E-mail: chenwei2011xjtu@gmail.com

Key words: bladder cancer, hypoxia, hypoxia inducible factor-1 $\alpha$, CCAAT/enhancer binding protein $\alpha$, expression and localization localization of $\mathrm{C} / \mathrm{EBP} \alpha$, which was markedly decreased in the nuclei under hypoxic conditions. Following HIF-1 $\alpha$ small interference RNA silencing of HIF-1 $\alpha$, downregulation of $\mathrm{C} / \mathrm{EBP} \alpha$ was prevented in the bladder cancer cells cultured under hypoxic conditions. In addition, groups of cells treated with 3-(5'-hydroxymethyl-2'-furyl)-1-benzylindazole, which inhibits the expression of HIF-1 $\alpha$ in hypoxia, contributed to the inhibited expression of HIF-1 $\alpha$ and enhanced expression of $\mathrm{C} / \mathrm{EBP} \alpha$ in hypoxic bladder cancer cells. These results suggested that $\mathrm{C} / \mathrm{EBP} \alpha$ was a downstream effector regulated by HIF-1 $\alpha$ in hypoxic bladder cancer cells and that this regulatory pathway may represent a potential therapeutic target in the treatment of bladder cancer.

\section{Introduction}

CCAAT/enhancer binding protein $\alpha(\mathrm{C} / \mathrm{EBP} \alpha)$ is a uniquely multifunctional transcription factor, which binds with the promoters of target genes and C/EBP family homodimers or heterodimers to regulate the transcription of target genes (1). In addition to its transcriptional activity, $\mathrm{C} / \mathrm{EBP} \alpha$ also promotes differentiation and suppresses proliferation in numerous cell types (2). These antiproliferative and pro-apoptotic characteristics of $\mathrm{C} / \mathrm{EBP} \alpha$ provide it with a tumor suppressive function in multiple tissues and it has been observed that downregulation of $\mathrm{C} / \mathrm{EBP} \alpha$ expression or $\mathrm{C} / \mathrm{EBP} \alpha$ gene mutations are associated with several human malignancies, including acute myeloid leukemia (3), lung cancer (4), breast cancer (5), hepatocellular carcinoma (6), head and neck squamous cell carcinoma (7) and skin cancer (8). Thus, $\mathrm{C} / \mathrm{EBP} \alpha$ has been recognized as a potential tumor suppressor and therapeutic target in human cancer.

As malignancy develops, the majority of types of solid tumor are characterized by hypoxic environments, which accelerate progression and metastasis (9). Bladder carcinoma is one of the common types of solid tumor associated with a hypoxic environment (10). The key hypoxic-responsive regulator of gene expression is hypoxia inducible factor-1 (HIF-1), which is a heterodimeric protein composed of a constitutively expressed $\beta$ subunit and an inducible $\alpha$ subunit (11). Under normoxic conditions, HIF-1 $\alpha$ mRNA is translated, but its protein is rapidly degraded (11). However, under hypoxic conditions, HIF-1 $\alpha$ protein becomes increasingly stabilized and its degradation is 
prevented, facilitating the regulation of the expression of a series of genes, which are involved in cell proliferation, differentiation, apoptosis, angiogenesis, migration and invasion (12). The overexpression of HIF-1 $\alpha$ has been identified in patients with bladder carcinoma, and the expression of HIF-1 $\alpha$ is correlated with the progression and recurrence of bladder carcinoma (13). Consequently, in addition to being a diagnostic biomarker, HIF-1 $\alpha$ may be a novel therapeutic target in bladder carcinoma. Although the involvement of HIF-1 $\alpha$ in the progression and metastasis of bladder cancer has previously been reported (14), the potential regulatory mechanisms of HIF-1 $\alpha$ on the proliferation and differentiation of bladder transitional carcinoma cancer cells has remained to be elucidated.

Based on the above observations, the present study hypothesized that HIF- $1 \alpha$ regulated the expression of $\mathrm{C} / \mathrm{EBP} \alpha$ in hypoxic bladder cancer cells and was involved in the regulation of the proliferation and differentiation of bladder cancer cells.

\section{Materials and methods}

Cell culture. The 5637 and T24 human bladder cancer cell lines were obtained from the American Type Culture Collection (Manassas, VA, USA). The cells were grown in RPMI-1640 (Gibco Life Technologies, Grand Island, NY, USA) with $10 \%$ fetal bovine serum. The cultures were maintained at $37^{\circ} \mathrm{C}$ under a humidified $5 \% \mathrm{CO}_{2}$ atmosphere.

Hypoxic treatment. Hypoxia was achieved by placing $50 \%$ confluent 5637 and T24 cells in an oxygen control incubator (Heal Force, Shanghai, China), which was flushed with a mixture of $1 \% \mathrm{O}_{2}, 94 \% \mathrm{~N}_{2}$ and $5 \% \mathrm{CO}_{2}$. The 5637 and $\mathrm{T} 24$ cells were incubated at $37^{\circ} \mathrm{C}$ for $48 \mathrm{~h}$ under the hypoxic conditions $\left(1 \% \mathrm{O}_{2}, 5 \% \mathrm{CO}_{2}\right.$ and $\left.94 \% \mathrm{~N}_{2}\right)$.

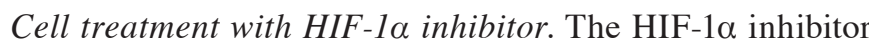
3-(5'-hydroxymethyl-2'-furyl)-1-benzylindazole (YC-1) was purchased from Sigma-Aldrich (St. Louis, MO, USA) and resuspended in dimethyl sulfoxide (DMSO; Sigma-Aldrich). YC-1 was used at a final concentration of $50 \mu \mathrm{mol} / 1$. The 5637 and T24 cells were incubated at $37^{\circ} \mathrm{C}$ for $12 \mathrm{~h}$ under hypoxic conditions $\left(1 \% \mathrm{O}_{2}, 5 \% \mathrm{CO}_{2}\right.$ and $\left.94 \% \mathrm{~N}_{2}\right)$. YC-1 or DMSO was added to RPMI-1640 medium prior to incubation for $12 \mathrm{~h}$ under hypoxic conditions. The final volume of YC-1 or DMSO in the medium was $\leq 0.5 \%(\mathrm{v} / \mathrm{v})$.

Small interference RNA (siRNA) transfection. The HIF-1a siRNA was transiently transfected into bladder cancer cell lines using X-tremeGENE siRNA transfection reagent (Roche Diagnostics, Indianapolis, IN, USA). The cells were transfected with HIF-1 $\alpha$ siRNA for $12 \mathrm{~h}$, following $24 \mathrm{~h}$ hypoxia. The HIF-1 $\alpha$ siRNAs (GenePharma, Shanghai, China) used are listed in Table I.

Reverse transcription-quantitative polymerase chain reaction (RT-qPCR). Total RNA was extracted from the bladder cancer cell lines using TRIzol reagent (Invitrogen Life Technologies, Carlsbad, CA, USA). First-strand cDNA was then synthesized using a PrimeScript RT reagent kit (Perfect Real-Time; Takara Biotechnology, Co., Ltd., Dalian, China). RT-qPCR was performed using a SYBR Premix Ex Taq ${ }^{\mathrm{TM}}$ II
(Takara Biotechnology, Co., Ltd.) in a CFX96 Real-Time PCR Detection system (Bio-Rad Laboratories, Inc., Hercules, CA, USA) and the results were normalized against $\beta$-actin as an internal control. The PCR cycling conditions were as follows: initial denaturation step at $95^{\circ} \mathrm{C}$ for $30 \mathrm{sec}$, followed by 40 cycles at $95^{\circ} \mathrm{C}$ for $5 \mathrm{sec}$ and $60^{\circ} \mathrm{C}$ for $30 \mathrm{sec}$. The PCR primers that were used are listed in Table I.

Western blotting. The bladder cancer cells were washed with phosphate-buffered saline (PBS), composed of $140 \mathrm{mM} \mathrm{NaCl}$, $2.7 \mathrm{mM} \mathrm{KCl}, 10 \mathrm{mM} \mathrm{Na}_{2} \mathrm{HPO}_{4}, 1.8 \mathrm{mM} \mathrm{KH}_{2} \mathrm{PO}_{4}(\mathrm{pH}$ 7.4), and lysed in radioimmunoprecipitation assay buffer (Thermo Fisher Scientific, Waltham, MA, USA) containing complete protease inhibitor cocktail tablets (Roche, one tablet/10 $\mathrm{ml}$ aqueous buffer). The protein concentrations were quantified using a bicinchoninic acid protein assay kit (Thermo Scientific; Pierce BCA Protein Assay Kit; cat. no. 23227). All proteins were separated by $10 \%$ SDS-PAGE and transferred onto nitrocellulose membranes (Pall Life Science, Port Washington, NY, USA). The membranes were incubated overnight at $4^{\circ} \mathrm{C}$ with the following primary antibodies: monoclonal rabbit anti-human $\mathrm{C} / \mathrm{EBP} \alpha$ antibody (1:500; Abcam; cat. no. ab40761), monoclonal mouse anti-human HIF-1 $\alpha$ antibody (1:500; Abcam; cat. no. ab1) and monoclonal mouse anti-human $\beta$-actin antibody (1:1000; Cell Signaling Technology, Beverly, MA, USA; cat. no. 3700). Following washing with TBST, composed of $20 \mathrm{mM}$ Tris, $140 \mathrm{mM} \mathrm{NaCl}$ and $0.5 \%$ Tween-20 (pH 7.6), the membranes were incubated with horseradish peroxidase-conjugated secondary antibodies (goat anti- rabbit/mouse immunoglobulin G; 1:2,000; Cell Signaling Technology; cat. no. 7074/7076) for $1 \mathrm{~h}$ at room temperature. Protein expression was assessed using enhanced chemiluminescent reagents (Pierce Biotechnology, Inc.).

Immunofluorescence analysis. The 5637 and T24 cells were fixed for $20 \mathrm{~min}$ at room temperature with $4 \%$ formaldehyde, permeabilized for $10 \mathrm{~min}$ at room temperature with $0.2 \%$ Triton $\mathrm{X}-100$, blocked for $1 \mathrm{~h}$ at room temperature with 5\% BSA and incubated overnight at $4^{\circ} \mathrm{C}$ with monoclonal rabbit anti-human $\mathrm{C} / \mathrm{EBP} \alpha$ (Abcam). The cells were subsequently incubated for $1 \mathrm{~h}$ at room temperature with $\mathrm{Cy} 3$-conjugated goat antirabbit immunoglobulin $\mathrm{G}$ (Invitrogen Life Technologies). The cellular nuclei were counterstained with 4',6-diamidino-2-phenylindole (Roche Diagnostics) and the cells were detected using a Nikon Eclipse Ti-S fluorescence microscope (Nikon Corp., Tokyo, Japan)..

Statistical analysis. All experiments were performed at least three times. The data are expressed as the mean \pm standard error of the mean and were analyzed using SPSS 19.0 (IBM SPSS, Armonk, NY, USA) and GraphPad Prism 5 software (GraphPad Software, Inc., San Diego, CA, USA). Statistical evaluations were determined using Student's two-tailed unpaired t-test. $\mathrm{P}<0.05$ was considered to indicate a statistically significant difference.

\section{Results}

Hypoxia induces changes in the gene expression of HIF-1 $\alpha$ and $C / E B P \alpha$ in bladder cancer cells. To confirm whether hypoxia regulated the expression of $\mathrm{C} / \mathrm{EBP} \alpha$ in bladder cancer cells, the 
Table I. Primer and siRNA sequences.

\begin{tabular}{llc}
\hline Gene & \multicolumn{1}{c}{ Sequence (5'-3') } & Experimental use \\
\hline C/EBP $\alpha$ & ATTGGAGCGGTGAGTTTG & RT-qPCR \\
& TTGGTGCGTCTAAGATGAG & \\
HIF- $1 \alpha$ & CATCTCCATCTCCTACCCACA & RT-qPCR \\
$\beta$-actin & CTTTTCTGCTCTGTTTGGTG & RT-qPCR \\
siRNA control & TCCCTGGAGAAGAGCTACGA & RNAi \\
HIF- $1 \alpha$ siRNA & AGCACTGTGTTGGCGTACAG & RNAi \\
& UUCUCCGAACGUGUCACGUTT & ACGUGACACGUUCGGAGAATT \\
& GCCUCUUUGACAAACUUAATT & UUAAGUUUGUCAAAGAGGCTT \\
\hline
\end{tabular}

siRNA, small interference RNA; C/EBP $\alpha$, CCAAT/enhancer binding protein $\alpha$; HIF-1 $\alpha$, hypoxia inducible factor-1 $\alpha$; RT-qPCR, reverse transcription-quantitative polymerase chain reaction; RNAi, RNA interference.

A

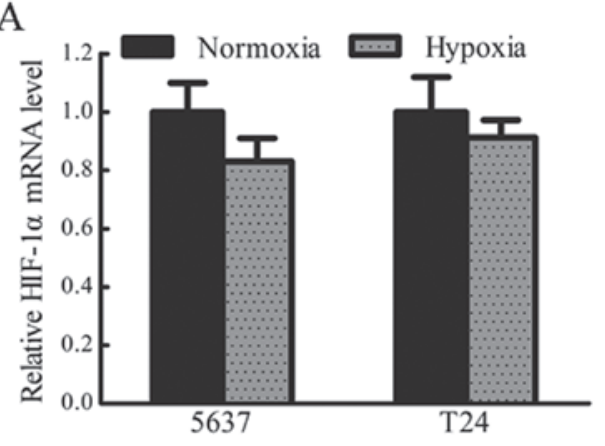

C

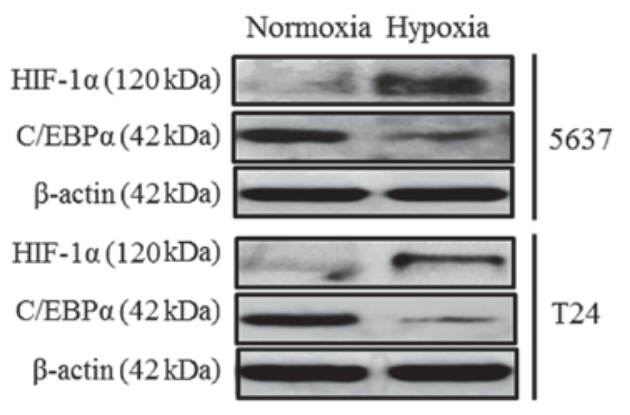

B
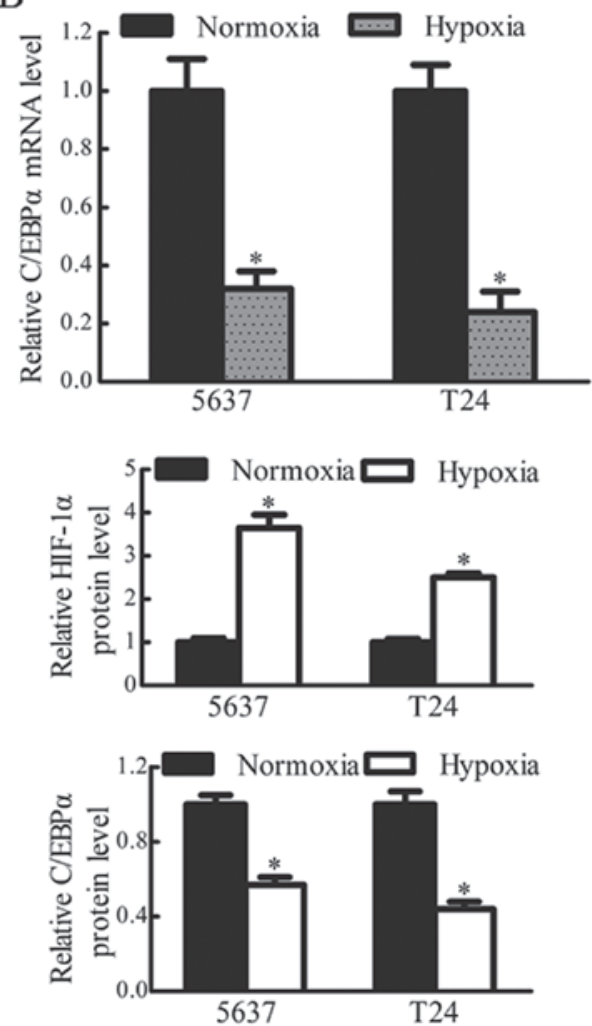

Figure 1. Hypoxia alters the gene expression levels of HIF-1 $\alpha$ and C/EBP $\alpha$ in 5637 and T24 bladder cancer cells. (A and B) mRNA expression levels of HIF-1 $\alpha$ and $\mathrm{C} / \mathrm{EBP} \alpha$ in normoxia and hypoxia were analyzed by reverse transcription-quantitative polymerase chain reaction. $\beta$-actin was used as an internal control. (C) $\mathrm{HIF}-1 \alpha$ and $\mathrm{C} / \mathrm{EBP} \alpha$ protein levels under normoxia and hypoxia were analyzed by western blotting. $\beta$-actin was used as an internal control. Values are expressed as the mean \pm standard error of the mean; ${ }^{*} \mathrm{P}<0.05 ; \mathrm{n}=3$. mRNA, messenger RNA; HIF-1 $\alpha$, hypoxia inducible factor-1 $\alpha$; $\mathrm{C} / \mathrm{EBP} \alpha, \mathrm{CCAAT} / \mathrm{enhancer}$ binding protein $\alpha$.

mRNA and protein expression levels of HIF-1 $\alpha$ and $\mathrm{C} / \mathrm{EBP} \alpha$ in the 5637 and T24 cells under hypoxic and normoxic conditions were determined. No significant differences were observed in the expression levels of HIF-1 $\alpha$ mRNA between the hypoxic and normoxic groups (Fig. 1A). Low protein expression levels of HIF-1 $\alpha$ were observed in the 5637 and T24 cells under normoxic culture conditions. However, the protein levels of
HIF-1 $\alpha$ were markedly upregulated ( 3 -fold increase) in the 5637 and T24 cells under hypoxic conditions, while the mRNA and protein levels of $\mathrm{C} / \mathrm{EBP} \alpha$ were significantly reduced, by 70 and $50 \%$ in the 5637 and T24 cells, respectively, under hypoxic conditions $(\mathrm{P}<0.05$; Fig. $1 \mathrm{~B}$ and $\mathrm{C})$. These data indicated that the downregulation of $\mathrm{C} / \mathrm{EBP} \alpha$ may be associated with the stable expression of HIF-1 $\alpha$ in hypoxic bladder cancer cells. 
A

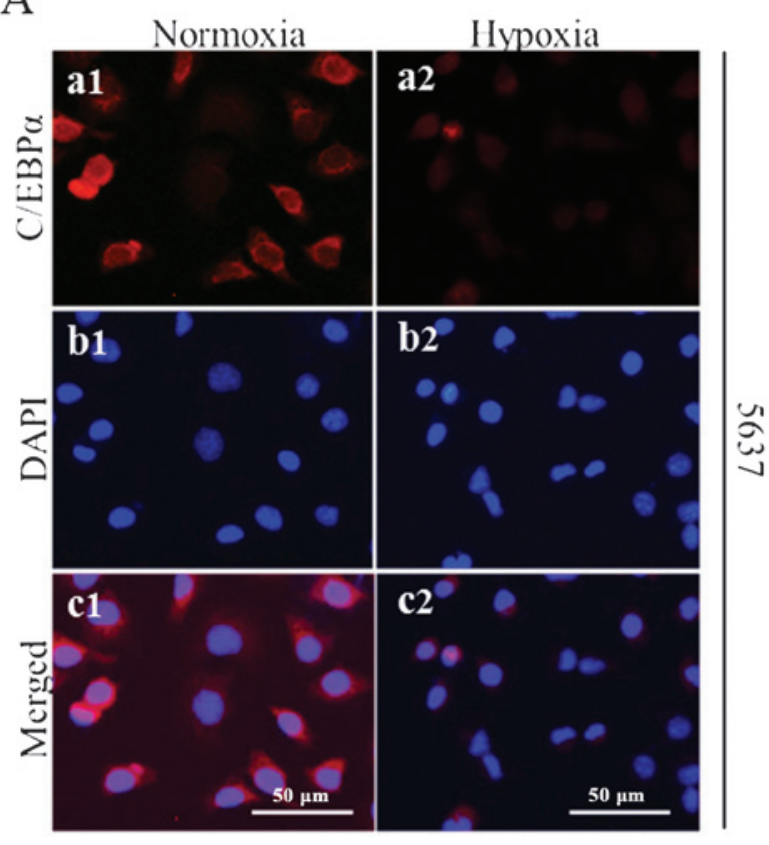

B

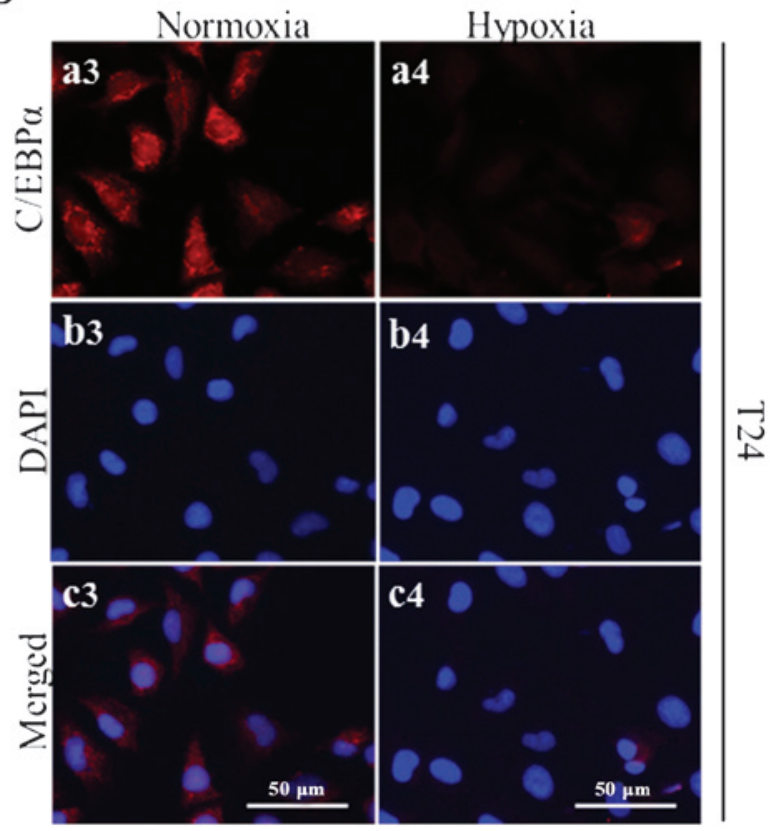

Figure 2. Hypoxia reduces the expression of $\mathrm{C} / \mathrm{EBP} \alpha$ in 5637 and $\mathrm{T} 24$ bladder cancer cells. Subcellular localization and protein expression levels of C/EBP $\alpha$ in hypoxic and normoxic bladder cancer cells. Immunofluorescence analysis of (a) C/EBP $\alpha$ (red) subcellular localization and (b) visualization of nuclei (DAPI, blue) in (A) 5637 and (B) T24 cells cultured under normoxic and hypoxic conditions. (Magnification, x100; scale bar, 50 $\mu$ m). C/EBP $\alpha$, CCAAT/enhancer binding protein $\alpha$.

Hypoxia reduces the expression of $C / E B P \alpha$ in bladder cancer cells. To further evaluate the differences in the expression of $\mathrm{C} / \mathrm{EBP} \alpha$ in hypoxia, the present study also analyzed the subcellular localization and protein levels of $\mathrm{C} / \mathrm{EBP} \alpha$ in the 5637 and T24 cells under hypoxic and normoxic culture conditions. The protein expression and subcellular localization of $\mathrm{C} / \mathrm{EBP} \alpha$ was detected using an immunofluorescence assay. Under normoxic culture conditions, the protein expression of $\mathrm{C} / \mathrm{EBP} \alpha$ was marked in the nucleus and cytoplasm of the bladder cancer cells (Fig. 2). However, under hypoxic conditions, the protein expression of $\mathrm{C} / \mathrm{EBP} \alpha$ was markedly decreased in the cytoplasm and, in particular, the nuclei of the 5637 and T24 bladder cancer cells. These data suggested that hypoxia reduced the nuclear localization of $\mathrm{C} / \mathrm{EBP} \alpha$ protein in the bladder cancer cells.

siRNA-mediated silencing of HIF-1 $\alpha$ enhances the expression of $C / E B P \alpha$ in hypoxic bladder cancer cells. In order to further confirm that HIF-1 $\alpha$ regulated the expression of $\mathrm{C} / \mathrm{EBP} \alpha$ in hypoxic bladder cancer cells, the 5637 and T2 4 cells were transfected with HIF-1 $\alpha$ siRNA or scrambled siRNA (siRNA control) prior to culture under hypoxic conditions. Transfection with the HIF-1 $\alpha$ siRNA led to a significant reduction in the mRNA and protein expression levels of HIF-1 $\alpha$, by $\sim 80$ and $\sim 50 \%$, respectively (Fig. 3A and B). Silencing of HIF-1 $\alpha$ may, therefore, prevent the downregulation of $\mathrm{C} / \mathrm{EBP} \alpha$ in hypoxic bladder cancer cells. Following treatment with HIF-1 $\alpha$ siRNA, the mRNA and protein levels of $\mathrm{C} / \mathrm{EBP} \alpha$ were rescued in the 5637 and T24 cells, exhibiting a 1.4 and 1.5 -fold increase, respectively (Fig. 3B and C). These results suggested that HIF-1 $\alpha$ was involved in the downregulation of $\mathrm{C} / \mathrm{EBP} \alpha$ in bladder cancer cells under hypoxic culture conditions.
$H I F-1 \alpha$ inhibitor $Y C-1$ enhances the expression of $C / E B P \alpha$ in hypoxic bladder cancer cells. YC-1 has been reported to be a novel anticancer drug targeting HIF-1 $\alpha$, which may also inhibit the expression of HIF-1 $\alpha(15,16)$. Therefore, the present study investigated whether bladder cancer cells treated with YC-1 exhibited alterations in the expression of HIF-1 $\alpha$ and $\mathrm{C} / \mathrm{EBP} \alpha$ under hypoxic conditions. The 5637 and T24 cells were treated with YC-1 (50 $\mu \mathrm{mol} / \mathrm{l})$ for $12 \mathrm{~h}$ under hypoxic conditions. The results revealed that YC-1 reduced the mRNA $(\sim 50 \%)$ and protein $(\sim 50 \%)$ expression of HIF-1 $\alpha$ under hypoxic conditions (Fig. 4A and B). YC-1 also prevented the downregulation of $\mathrm{C} / \mathrm{EBP} \alpha$ in the hypoxic bladder cancer cells. The mRNA and protein levels of $\mathrm{C} / \mathrm{EBP} \alpha$ were enhanced $\sim 1.8$ and 2-fold, respectively, following treatment with $\mathrm{YC}-1$ in the 5637 and T24 cells (Fig. 4B and C). These data confirmed that YC-1 inhibited the expression of HIF-1 $\alpha$ and enhanced the expression of $\mathrm{C} / \mathrm{EBP} \alpha$ in hypoxic bladder cancer cells.

\section{Discussion}

Hypoxia is one of the most fundamental and common biological phenomena found in various types of solid tumor, including bladder cancer (17). As a response to the hypoxic environment, HIF-1 $\alpha$ is activated in cancer cells, and contributes to cellular adaptation and survival (12). A number of genes, which have been implicated in angiogenesis, invasion, metastasis, cell proliferation, differentiation and apoptosis, are regulated by HIF-1 $\alpha$ (18). The roles of HIF-1 $\alpha$ in tumor angiogenesis, invasion and metastasis have previously been investigated, whereas the molecular regulatory mechanisms underlying the involvement of HIF-1 $\alpha$ in tumor cell proliferation and differentiation have remained to be fully elucidated. Previous studies have demonstrated that, in breast cancer cells, hypoxia induces 
A

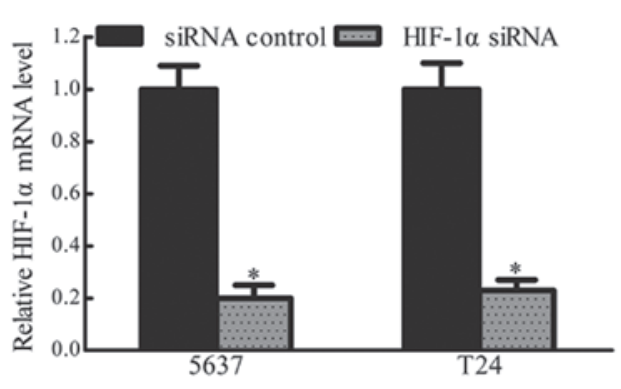

B

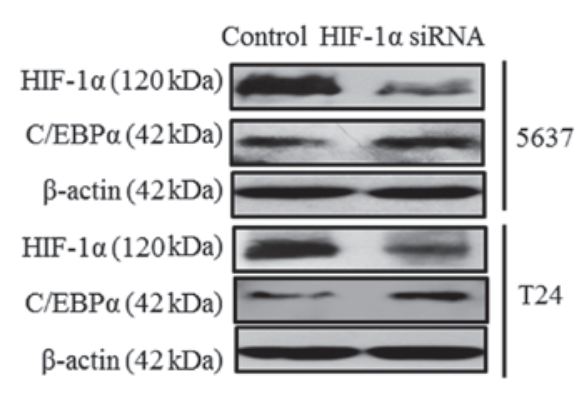

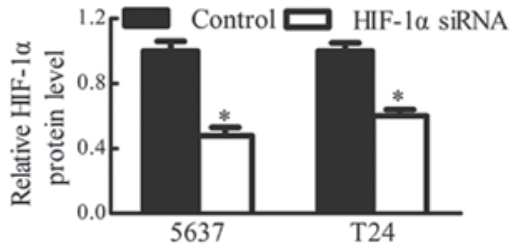

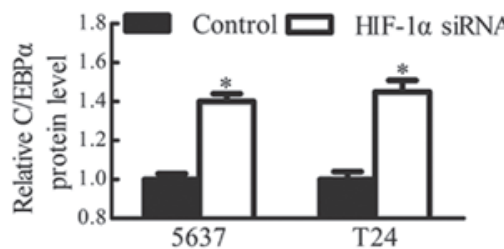

$\mathrm{C}$

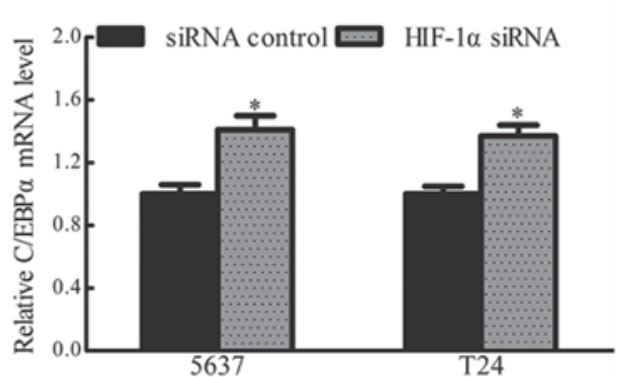

Figure 3. HIF-1 $\alpha$ restores the expression of $\mathrm{C} / \mathrm{EBP} \alpha$ in hypoxic bladder cancer cells. Following treatment of 5637 and T24 cells with HIF-1 $\alpha$ siRNA (A and B) mRNA levels of HIF-1 $\alpha$ and $\mathrm{C} / \mathrm{EBP} \alpha$ were analyzed by quantitative polymerase chain reaction and (C) protein levels of HIF-1 $\alpha$ and $\mathrm{C} / \mathrm{EBP} \alpha$ were analyzed by western blotting. $\beta$-actin was used as an internal control. Values are expressed as the mean \pm standard error of the mean; ${ }^{*} \mathrm{P}<0.05$; $\mathrm{n}=3$. $\mathrm{mRNA}$, messenger RNA; HIF-1 $\alpha$, silencing hypoxia inducible factor- $1 \alpha$; C/EBP $\alpha$, CCAAT/enhancer binding protein $\alpha$; siRNA, short interference RNA.

A

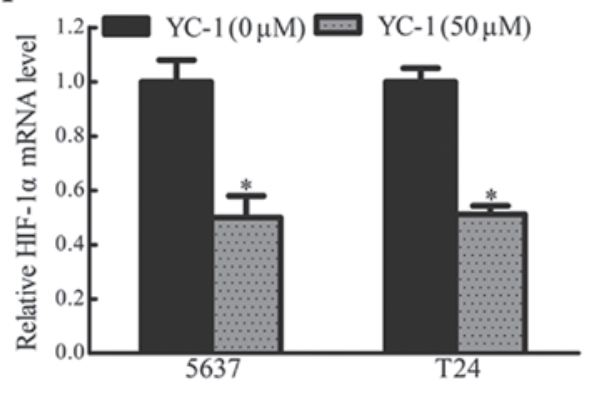

B

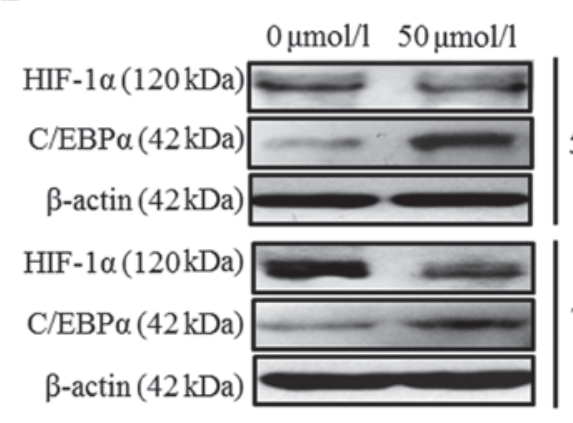

$\mathrm{C}$

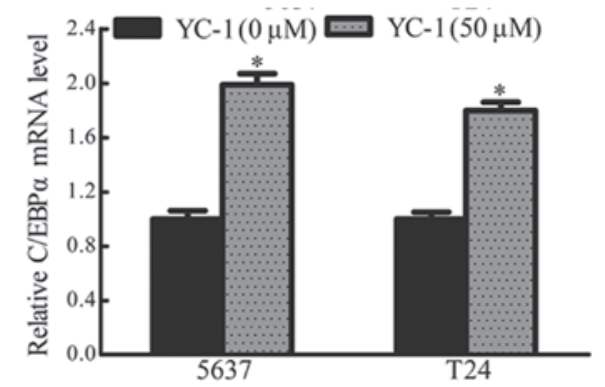

5637

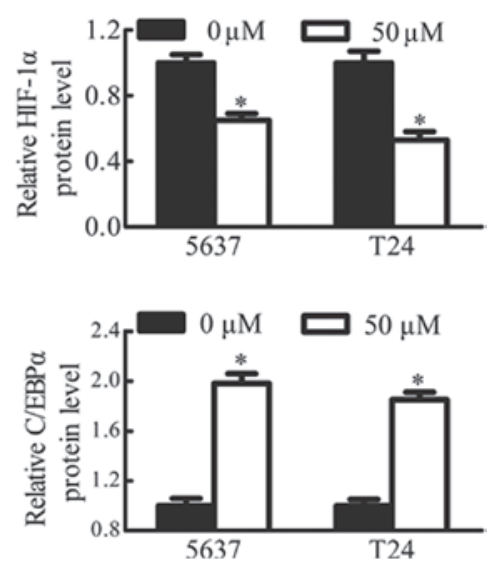

Figure 4. HIF-1 $\alpha$-specific inhibitor YC-1 enhances the expression of C/EBP $\alpha$ in hypoxic bladder cancer cells. Following treatment of 5637 and T24 cells with YC-1 $(50 \mu \mathrm{mol} / \mathrm{l})(\mathrm{A}$ and B) mRNA levels of HIF-1 $\alpha$ and C/EBP $\alpha$ were analyzed by quantitative polymerase chain reaction and (C) protein levels of HIF-1 $\alpha$ and C/EBP $\alpha$ were analyzed by western blotting. $\beta$-actin was used as an internal control. Values are expressed as the mean \pm standard error of the mean; ${ }^{*} \mathrm{P}<0.05 ; \mathrm{n}=3$. mRNA, messenger RNA; HIF-1 $\alpha$, silencing hypoxia inducible factor-1 $\alpha$; $/ \mathrm{EBP} \alpha, \mathrm{CCAAT} / \mathrm{enhancer}$ binding protein $\alpha$; YC-1, 3-(5'-hydroxymethyl-2'-furyl)-1-benzylindazole .

downregulation of the expression of C/EBP $(19,20)$, which indicated that hypoxia modulates breast cancer cell proliferation and differentiation, potentially through downregulation of $\mathrm{C} / \mathrm{EBP} \alpha$. However, to the best of our knowledge, there is no current evidence indicating that hypoxia regulates the expression and subcellular localization of C/EBP $\alpha$ in bladder 
carcinoma. In the present study, hypoxia was found to downregulate the expression and nuclear localization of the tumor suppressor C/EBP $\alpha$ through an HIF-1 $\alpha$-dependent mechanism in bladder transitional carcinoma cells. Therefore, HIF-1 $\alpha$ may be involved in regulating the differentiation and proliferation of bladder cancer cells by controlling the expression of $\mathrm{C} / \mathrm{EBP} \alpha$.

$\mathrm{C} / \mathrm{EBP} \alpha$ inhibits proliferation and induces differentiation in several cell types through protein-protein interactions (21-25). Several mechanisms for these effects have been proposed, including stabilization of p21 $(21,22)$, repression of E2F (23), direct inhibition or degradation of Cdk2 and Cdk4 (24) and interaction with the SWI/SNF chromatin remodeling complex (25). Therefore, $\mathrm{C} / \mathrm{EBP} \alpha$, through multiple mechanisms, functions as a tumor suppressor in tumorigenesis, however, further investigation is required to determine the exact function and mechanism of $\mathrm{C} / \mathrm{EBP} \alpha$ in bladder cancer cell differentiation and proliferation.

The functional activity of $\mathrm{C} / \mathrm{EBP} \alpha$ is regulated by modulation of its intracellular localization (26). $\mathrm{C} / \mathrm{EBP} \alpha$ requires localization in the nuclear region to exert its capacity for transcriptional activation and its biological function (19). Previous studies have demonstrated that $\mathrm{C} / \mathrm{EBP} \alpha$ is localized in the nucleus in normal epithelial cells; however, in cancer cells, $\mathrm{C} / \mathrm{EBP} \alpha$ is localized in the nucleus and cytoplasm (27). The present study also found that $\mathrm{C} / \mathrm{EBP} \alpha$ exhibited mixed nuclear and cytoplasmic localization in the bladder cancer cells. However, hypoxia markedly decreased the expression of $\mathrm{C} / \mathrm{EBP} \alpha$ in the nuclear region of the 5637 and T24 cells (Fig. 2B). The reduction of $\mathrm{C} / \mathrm{EBP} \alpha$ within the bladder cancer cell nuclei under hypoxia may contribute to a decrease in the biological activity of this protein. Thus, hypoxia regulated the biological effects of $\mathrm{C} / \mathrm{EBP} \alpha$ by modulating the nuclear localization of $\mathrm{C} / \mathrm{EBP} \alpha$.

$\mathrm{YC}-1$ is reported to be a novel antitumor agent, which decreases the expression of HIF-1 $\alpha$, inhibiting cell proliferation and inducing apoptosis in hypoxic bladder cancer cells $(15,16)$. However, the antitumor mechanism of YC-1 in bladder cancer remains to be fully elucidated. The present study observed that YC-1 inhibited the expression of HIF-1 $\alpha$ and prevented the downregulation of $\mathrm{C} / \mathrm{EBP} \alpha$ in hypoxic bladder cancer cells. These findings indicated that YC-1 may exert antitumor effects through the HIF- $1 \alpha$ and $\mathrm{C} / \mathrm{EBP} \alpha$ pathway in hypoxic bladder cancer cells.

In conclusion, the present study demonstrated that, in bladder cancer cells, hypoxia downregulated the expression and nuclear localization of $\mathrm{C} / \mathrm{EBP} \alpha$, a process which was mediated by HIF-1 $\alpha$. Furthermore, the HIF-1 $\alpha$ specific inhibitor, $\mathrm{YC}-1$, rescued the downregulation of $\mathrm{C} / \mathrm{EBP} \alpha$ under hypoxic conditions. Future investigations using bladder cancer tissue specimens to analyze the association between the expression of HIF- $1 \alpha$ and C/EBP $\alpha$ and clinical and pathological parameters and patient survival rates are required to evaluate $\mathrm{C} / \mathrm{EBP} \alpha$ as a potential therapeutic target in bladder cancer.

\section{Acknowledgements}

This study was supported by grants (nos. 81171970, 81072104 and 30370660) from the National Natural Science Foundation of China.

\section{References}

1. Schuster MB and Porse BT: C/EBPalpha: a tumour suppressor in multiple tissues? Biochim Biophys Acta 1766: 88-103, 2006.

2. Lopez RG, Garcia-Silva S, Moore SJ, Bereshchenko O, Martinez-Cruz AB, Ermakova O, Kurz E, Paramio JM and Nerlov C: C/EBPalpha and beta couple interfollicular keratinocyte proliferation arrest to commitment and terminal differentiation. Nat Cell Biol 11: 1181-1190, 2009.

3. Pabst T, Mueller BU, Zhang P, Radomska HS, Narravula S, Schnittger S, Behre G, Hiddemann $W$ and Tenen DG: Dominant-negative mutations of CEBPA, encoding CCAAT/enhancer binding protein-alpha (C/EBPalpha), in acute myeloid leukemia. Nat Genet 27: 263-270, 2001.

4. Sato A, Yamada N, Ogawa Y and Ikegami M: CCAAT/enhancer-binding protein- $\alpha$ suppresses lung tumor development in mice through the p38 $\alpha$ MAP kinase pathway. PLoS One 8: e57013, 2013.

5. Gery S, Tanosaki S, Bose S, Bose N, Vadgama J and Koeffler HP: Down-regulation and growth inhibitory role of C/EBPalpha in breast cancer. Clin Cancer Res 11: 3184-3190, 2005.

6. Tseng HH, Hwang YH, Yeh KT, Chang JG, Chen YL and Yu HS: Reduced expression of C/EBP alpha protein in hepatocellular carcinoma is associated with advanced tumor stage and shortened patient survival. J Cancer Res Clin Oncol 135: 241-247, 2009.

7. Bennett KL, Hackanson B, Smith LT, Morrison CD, Lang JC, Schuller DE, Weber F, Eng C and Plass C: Tumor suppressor activity of CCAAT/enhancer binding protein alpha is epigenetically down-regulated in head and neck squamous cell carcinoma. Cancer Res 67: 4657-4664, 2007.

8. Thompson EA, Zhu S, Hall JR, House JS, Ranjan R, Burr JA, He YY, Owens DM and Smart RC: C/EBP $\alpha$ expression is downregulated in human nonmelanoma skin cancers and inactivation of $\mathrm{C} / \mathrm{EBP} \alpha$ confers susceptibility to UVB-induced skin squamous cell carcinomas. J Invest Dermatol 131: 1339-1346,2011.

9. Keith B and Simon MC: Hypoxia-inducible factors, stem cells, and cancer. Cell 129: 465-472, 2007.

10. Tickoo SK, Milowsky MI, Dhar N, Dudas ME, Gallagher DJ, Al-Ahmadie H, Gopalan A, Fine SW, Ishill N, Bajorin DF and Reuter VE: Hypoxia-inducible factor and mammalian target of rapamycin pathway markers in urothelial carcinoma of the bladder: possible therapeutic implications. Bju Int 107: 844-849, 2011.

11. Majmundar AJ, Wong WJ and Simon MC: Hypoxia-inducible factors and the response to hypoxic stress. Mol Cell 40: 294-309, 2010.

12. Semenza GL: Targeting HIF-1 for cancer therapy. Nat Rev Cancer 3: 721-732, 2003.

13. Chai CY, Chen WT, Hung WC, Kang WY, Huang YC, Su YC and Yang $\mathrm{CH}$ : Hypoxia-inducible factor-1alpha expression correlates with focal macrophage infiltration, angiogenesis and unfavourable prognosis in urothelial carcinoma. J Clin Pathol 61: 658-664, 2008.

14. Zhang T, Fan J, Wu K, Zeng J, Sun K, Guan Z, Wang X, Hiesh JT and He D: Roles of HIF-l $\alpha$ in a novel optical orthotopic spontaneous metastatic bladder cancer animal model. Urol Oncol 30: 928-935, 2012.

15. Li Y, Zhao X, Tang H, Zhong Z, Zhang L, Xu R, Li S and Wang Y: Effects of YC-1 on hypoxia-inducible factor 1 alpha in hypoxic human bladder transitional carcinoma cell line T24 cells. Urol Int 88: 95-101, 2012.

16. Sun HL, Liu YN, Huang YT, Pan SL, Huang DY, Guh JH, Lee FY, Kuo SC and Teng CM: YC-1 inhibits HIF-1 expression in prostate cancer cells: contribution of Akt/NF-kappaB signaling to HIF-1alpha accumulation during hypoxia. Oncogene 26: 3941-3951, 2007

17. Gospodarowicz M: Combination therapy: hypoxia modification with radiotherapy for bladder cancer. Nat Rev Clin Oncol 8: 129-130, 2011.

18. Choi SB, Park JB, Song TJ and Choi SY: Molecular mechanism of HIF-1-independent VEGF expression in a hepatocellular carcinoma cell line. Int J Mol Med 28: 449-454, 2011.

19. Seifeddine R, Dreiem A, Blanc E, Fulchignoni-Lataud MC, Le Frère Belda MA, Lecuru F, Mayi TH, Mazure N, Favaudon V, Massaad C, et al: Hypoxia down-regulates CCAAT/enhancer binding protein-alpha expression in breast cancer cells. Cancer Res 68: 2158-2165, 2008.

20. Seifeddine R, Fulchignoni-Lataud MC and Massaad-Massade L: Down-regulation of $\mathrm{C} / \mathrm{EBP} \alpha$ in breast cancer cells by hypoxia-estrogen combination is mainly due to hypoxia. Anticancer Res 29: 1227-1231, 2009. 
21. TimchenkoNA,Harris TE,WildeM,BilyeuTA,Burgess-BeusseBL, Finegold MJ and Darlington GJ: CCAAT/enhancer binding protein alpha regulates $\mathrm{p} 21$ protein and hepatocyte proliferation in newborn mice. Mol Cell Biol 17: 7353-7361, 1997.

22. Timchenko NA, Wilde M, Nakanishi M, Smith JR and Darlington GJ: CCAAT/enhancer-binding protein alpha (C/EBP alpha) inhibits cell proliferation through the p21 (WAF-1/CIP-1/SDI-1) protein. Genes Dev 10: 804-815, 1996.

23. Zaragoza K, Bégay V, Schuetz A, Heinemann U and Leutz A: Repression of transcriptional activity of C/EBPalpha by E2F-dimerization partner complexes. Mol Cell Biol 30: 2293-2304, 2010.

24. Yin H, Lowery $M$ and Glass J: In prostate cancer C/EBPalpha promotes cell growth by the loss of interactions with CDK2, CDK4, and E2F and by activation of AKT. Prostate 69: 1001-1016, 2009.
25. Muller C, Calkhoven CF, Sha X and Leutz A: The CCAAT enhancer-binding protein alpha $(\mathrm{C} / \mathrm{EBPalpha})$ requires a SWI/SNF complex for proliferation arrest. J Biol Chem 279: 7353-7358, 2004.

26. Zhang J, Wilkinson JE, Gonit M, Keck R, Selman S and Ratnam M: Expression and sub-cellular localization of the CCAAT/enhancer binding protein $\alpha$ in relation to postnatal development and malignancy of the prostate. Prostate 68: 1206-1214, 2008

27. Kumagai T, Akagi T, Desmond JC, Kawamata N, Gery S, Imai Y, Song JH, Gui D, Said J and Koeffler HP: Epigenetic regulation and molecular characterization of C/EBPalpha in pancreatic cancer cells. Int J Cancer 124: 827-833, 2009. 